\title{
Lymphoblasts More Than 50 Percent of Bone Marrow Nucleated Cells
}

National Cancer Institute

\section{Source}

National Cancer Institute. Lymphoblasts More Than 50 Percent of Bone Marrow

Nucleated Cells. NCI Thesaurus. Code C156386.

A semi-quantitative microscopic finding indicating that more than 50 percent of the nucleated cells in a bone marrow sample are immature mononuclear cells of lymphoid origin. 